\title{
O noticiário criminal e os repórteres policiais dos jornais da cidade do Rio de Janeiro no início do século XX
}

\author{
The criminal news and the police reporters of the newspapers of the city of Rio de \\ Janeiro in the early twentieth century
}

\author{
Thiago Torres Medeiros da Silva \\ Doutorando em História Social pela \\ Universidade Federal do Rio de Janeiro \\ torres_ufrrj@hotmail.com
}

Resumo: No presente artigo, objetivamos reconstituir a trajetória dos repórteres policiais da cidade do Rio de Janeiro no início do século $\mathrm{XX}$. Neste período, alguns desses repórteres foram testemunhas nos processos criminais de assassinatos ocorridos na Capital Federal. Dessa forma, pretendemos apresentar esses casos e, em seguida, tentaremos recompor a trajetória desses personagens. Com este fito, seguiremos os vestígios dos repórteres nas páginas dos impressos cariocas. No entanto, antes disso, iremos expor algumas características que ilustram o sucesso das notícias de crimes no cotidiano da cidade. A predileção do público foi determinante para a intensa divulgação dos crimes na imprensa. Palavras-chave: Jornal; processo criminal; repórter policial.

\begin{abstract}
In this article, we aim to reconstitute the trajectory of police reporters in the city of Rio de Janeiro at the beginning of the 20th century. During this period, some of these reporters were witnesses in the criminal proceedings of murders in the Federal Capital. In this way, we intend to present these cases and then try to recompose the trajectory of these characters. With this aim, we will follow the vestiges of the reporters in the pages of the Rio printed. However, before this, we will expose some characteristics that illustrate the success of crime news in the daily life of the city. The predilection of the public was decisive for the intense dissemination of crimes in the press.
\end{abstract}

Keywords: Newspaper; criminal process; police reporter. 


\section{Introdução}

No presente trabalho, pretendemos recompor a trajetória de alguns repórteres policiais da cidade do Rio de Janeiro no início do século XX. Estes indivíduos eram os responsáveis pela elaboração dos relatos sobre os crimes cometidos no cotidiano da Capital Federal. O repórter entrava em cena sempre que ocorria um crime que mobilizava a atenção do público. Nestas ocasiões, ele se dirigia para a "cena de sangue" em busca de maiores detalhes sobre o fato criminoso. Após essa coleta de informações, o repórter construía a notícia que seria estampada no dia seguinte. Estas matérias de crimes eram publicadas sem qualquer indicação de autoria, uma vez que os repórteres não assinavam esses relatos.

Neste sentido, enfrentamos um grande obstáculo para identificar esses personagens. Em trabalho anterior, pretendíamos cotejar os relatos dos homicídios expostos nos jornais cariocas com os depoimentos presentes nos processos criminais. Com isso, objetivávamos mapear as semelhanças e diferenças entre a linguagem da imprensa e a linguagem presente nos autos judiciais. Ao todo, analisamos 129 processos de homicídios custodiados pelo Arquivo do Museu da Justiça do Estado do Rio de Janeiro. Para nossa surpresa, em quatro processos consultados nos deparamos com alguns funcionários da imprensa.

Dessa forma, buscaremos apresentar esses casos e tentaremos reconstituir a trajetória profissional desses repórteres que foram testemunhas nos processos instaurados pela Justiça criminal. Porém, antes disso, é interessante apresentarmos algumas características que ilustram o grande sucesso das notícias de crimes no cotidiano da sociedade carioca.

\section{Os populares e o noticiário criminal}

Em primeiro lugar, poderíamos nos questionar como os leitores decodificavam as notícias dos crimes praticados na capital da República. Segundo Marialva Barbosa, esta poderia se dar de diversas formas, até mesmo relacionar a realidade com a fantasia (1997: 100). Em outras palavras, o leitor poderia compreender o cotidiano da cidade, permeado de conflitos sangrentos, mesclado aos elementos ficcionais encontrados nas 
obras literárias. Dessa forma, os leitores confundiriam os atores dos dramas da cidade com os personagens encontrados nas páginas do romance ${ }^{1}$.

Essa confusão era até justificável, uma vez que os jornais também publicavam no formato de folhetim algumas histórias ficcionais envolvendo crimes, geralmente expostas no rodapé das páginas. Portanto, a aproximação destas narrativas revela que a interpretação do leitor poderia transitar entre o real e o imaginário.

Além disso, evidencia-se outra apropriação dos elementos utilizados em romances criminais por parte dos repórteres policiais. Estes, ao construírem seus relatos sobre os crimes reais lançavam mão de artefatos próprios dos escritores de romances de crime. Entre estes recursos, um especial foi bastante preponderante: a utilização de uma linguagem que valoriza o suspense e o mistério na elucidação dos crimes, característica principal nos romances criminais expostos no rodapé da página ${ }^{2}$. Nesse sentido, as narrativas de crimes "tornam-se construções literárias, as quais, se por um lado deixavam a leitura mais instigante e enfática, por outro possuíam forte ligação com o naturalismo vigente no momento" (PORTO, 2003: 26).

No que diz respeito à recepção do público para com o noticiário criminal, nos deparamos com algumas passagens nas obras literárias do período que nos dão um interessante panorama das possibilidades da repercussão dessas notícias no meio social. Lima Barreto descrevendo o cotidiano e ambiente da redação aponta que certa vez pregaram a notícia de um crime na porta do jornal, logo, "o primeiro curioso que passou, parou e quedou-se a ler. Vieram outros e em breve uma multidão estacionava" ali em frente. Barreto compara a propagação da notícia com a "rapidez de um telégrafo" e "com a velocidade espantosa da eletricidade".

Em suas crônicas, Orestes Barbosa também teceu comentários sobre a maneira pela qual os populares se relacionavam com os crimes presentes nas páginas dos jornais. Ao descrever a caftina Alice Cavalo de Pau, disse que quando surgiu o crime da Rua da

\footnotetext{
${ }^{1}$ Os romances eram bastante divulgados na imprensa no formato de folhetim. Nesse período, desfrutavam de enorme prestígio entre o público, as obras dos autores franceses Xavier de Montépin e Pouson Du Terrail. Vale ressaltar que a divulgação desses folhetins era compartilhada por todos os grandes jornais da cidade do Rio de Janeiro.

2 A apresentação do mistério já era anunciada no título da reportagem. Além disso, no início da narrativa o jornalista ainda reforça o caráter enigmático de alguns crimes, como podemos observar neste relato: “envolvido no mais profundo mistério, deu-se há pouco dias na nossa formosa baía de Guanabara um desses crimes, cujo protagonista demonstra ter descido o último do degrau da degeneração humana". "Crime misterioso" (JORNAL DO BRASIL, 14/01/1902: 1). No decorrer da narrativa o repórter procura prolongar o efeito do suspense, passando a revelar alguns detalhes somente nos últimos momentos da reportagem. Esta maneira de narrar era muito comum nos folhetins.
} 
Carioca $^{3}$, "ela queria saborear as narrativas do crime de Rocca e Carleto. Aprendeu a ler e saboreou" (BARBOSA, 1933: 92).

No entanto, nem todos os crimes mobilizavam esse esforço demonstrado por Alice, chegando ao ponto dela aprender a ler. Lima Barreto em Clara dos Anjos ressalta que somente os crimes envoltos em circunstâncias misteriosas calhavam de monopolizar a atenção do público. Para estes crimes, "faz sempre trabalhar todas as imaginações de uma cidade" (BARRETO, 1999: 113). Inversamente, "um homicídio banal em que se conheceu a causa, o autor, capturado ou não, e outros pormenores, deixa de oferecer interesse, para ser um acontecimento banal na vida urbana" (BARRETO, 1999: 113).

Contudo, não eram escassos os homicídios que impactavam fortemente a população da cidade, sendo que nessas ocasiões "faz parecer a toda a gente que há, soltos e esbarrando conosco nas ruas, nas praças, nos bondes, nas lojas, nos trens, matadores" (BARRETO, 1999: 113). Nesse momento, deveria ser comum que as pessoas buscassem, cada qual ao seu modo, explicações sobre os possíveis motivos que levaram ao crime.

Além disso, alguns intelectuais do período chegaram a recear os efeitos do noticiário criminal para a mente dos populares. A. Lowenstimm procurou refletir sobre a influência das superstições populares nas práticas de crimes. Em determinado momento do seu trabalho, o autor advertiu que juntamente com a educação que as crianças recebiam na primeira infância "a leitura ou audição de notícias de assassinato, relatados nos jornais e historiados romances, se os não levam diretamente" a executar estes crimes, "ensinaos, dada a ocasião propícia, a empregar meios que eles leram ou ouviram ler" (LOWENSTIMM, 1905: 15-16). Em outras palavras, o autor acreditava que a divulgação desses crimes na imprensa, fossem eles "reais" ou "fictícios", influenciava no estado mental dos indivíduos, principalmente aqueles oriundos dos setores mais populares.

Por um tempo considerável as fontes jornalísticas foram desqualificadas pelos historiadores no fomento de suas pesquisas. $\mathrm{O}$ argumento mais recorrente era de que a imprensa veiculava apenas imagens parciais da realidade do cotidiano da cidade. Além disso, os conteúdos articulados nos jornais serviriam apenas aos interesses das classes dominantes, ou seja, as notícias seriam apenas instrumentos de dominação de classe. De

\footnotetext{
${ }^{3}$ Em linhas gerais, o crime da Rua da Carioca foi um dos crimes de maior repercussão da cidade do Rio de Janeiro nas primeiras décadas do século XX. Em noite de 14 de outubro de 1906, uma quadrilha de ladrões, chefiada por Carleto e Rocca, assassinaram os irmãos Paulino e Carluccio Fuoco. Estes jovens eram sobrinhos de Jacob Fuoco, proprietário de uma joalheria situada na Rua da Carioca. Os líderes da quadrilha cometeram o duplo assassinato para roubar às joias do estabelecimento comercial. Este latrocínio e os desdobramentos da investigação policial foram intensamente noticiados por quase todos os jornais da Capital Federal.
} 
acordo com esta perspectiva, os grupos populares tinham pouca influência na seleção destas notícias.

No entanto, com o grande destaque dado ao noticiário criminal, percebemos que os leitores interferiam diretamente na escolha dos assuntos narrados pelos periódicos. Segundo Marialva Barbosa, os jornais readequariam os seus conteúdos em vista de atender a uma "demanda cultural do público e não ao contrário" (1997: 98). Dessa maneira, em última instância, foi o público que se materializou no principal agente responsável pelas transformações evidenciadas nas temáticas e nos editoriais dos periódicos.

Luiz Edmundo observa a existência de uma predileção do público por notícias de crimes. $\mathrm{O}$ autor, ao descrever os periódicos no início do século $\mathrm{XX}$, cita que o jornal era movimentado, alegre e vivo. Não obstante, ele faz algumas ponderações. Segundo o autor, "o que possui de mau não é dele, é do tempo, herdou. Há rotinas que se herdam e que ficam. Explora, a folha, como imprensa que se tem por moderna, escândalo com os quais, o público, constantemente, se entretém" (EDMUNDO, 2003: 592). Este depoimento é elucidativo de que o público tinha uma parcela dos seus interesses sendo representada nas páginas dos jornais, contrariando àqueles que percebiam as folhas somente como representativas dos grupos dominantes.

Nesse sentido, poderíamos nos questionar quem eram os indivíduos encarregados pela elaboração das notícias dos crimes cometidos na cidade do Rio de Janeiro no início do século XX. Assim sendo, pretendemos analisar as trajetórias de alguns repórteres policiais nas primeiras décadas do século passado.

\section{A presença dos repórteres nos processos criminais da primeira década do século XX no Rio de Janeiro}

Neste item, tentaremos recompor as trajetórias dos funcionários que trabalhavam na imprensa carioca do início do século XX. Mais precisamente, nosso objetivo principal será acompanhar os vestígios deixados por alguns repórteres policiais. Vale ressaltar que foi neste período que as notícias de crimes invadiram as páginas dos principais periódicos da capital da República ${ }^{4}$.

\footnotetext{
${ }^{4}$ De acordo com Ana Porto, foi "relevante o grande destaque dado às notícias de crime nos anos de $1900 \mathrm{e}$ 1910" (2003: 32).
} 
Em sua primeira fase, os jornais eram gestados para instruir politicamente os leitores, com isso, os artigos abordavam as questões pertinentes aos escalões do governo, narrando a atuação dos políticos e o comportamento dos indivíduos situados nas altas esferas do poder. Porém, a partir do final do século XIX, os periódicos lançaram diversas estratégias para atrair o público, e a divulgação das notícias de crimes fazia parte desta tentativa de aproximação do cotidiano dos leitores e ouvintes.

Esta sensível variação na temática dos jornais foi fruto de um momento de intensas transformações ocorridas nas estruturas dos jornais. Em uma nova lógica de funcionamento, o jornal para garantir sua sobrevivência dependeria do aumento da vendagem. Ou seja, os periódicos não se sustentavam apenas pela arrecadação do montante das assinaturas. É neste contexto de tentativa de ampliação do número de vendagens e do incremento da publicidade ${ }^{5}$ que o noticiário sobre crimes se intensificou nas páginas dos periódicos. Como observa Ana Ottoni, por meio das reportagens policiais, os jornais "pareciam buscar representar os mais variados interesses e perspectivas dos mais diferentes grupos, incluindo os dos setores médios e pobres da população" (2012: 12).

Por conseguinte, todos os grandes diários cariocas, sem exceção, passaram a divulgar com maior frequência os crimes perpetrados no cotidiano da Capital Federal. Neste sentido, poderíamos nos questionar quem eram os indivíduos responsáveis pela elaboração das notícias. Importante lembrar que as matérias criminais não eram assinadas pelo repórter, ou seja, não podemos determinar a autoria somente com a leitura da notícia.

No entanto, como já foi salientado, em alguns processos criminais consultados no Arquivo do Museu da Justiça do Estado do Rio de Janeiro, nos deparamos com alguns funcionários da imprensa que depuseram na sede da delegacia e/ou da pretoria. Isso nos indica que em algumas circunstâncias havia uma estreita relação entre os repórteres e as autoridades policiais e judiciárias. Com o fito de exemplificarmos esta proximidade apresentaremos os casos em que os jornalistas se transfiguraram em testemunhas.

No dia 5 de abril de 1900, o repórter Henrique Autran da Motta Albuquerque, nascido na Capital Federal, 26 anos, casado e residente na Rua Barão de Mesquita, 42,

\footnotetext{
${ }^{5}$ Além dos jornais terem ampliado o número de leitores para as suas obras literárias, escritores como Bastos Tigre, Olavo Bilac e Emílio de Meneses enveredaram no ramo da publicidade com a criação de versosreclame para os produtos e marcas anunciadas nos impressos. Quer dizer, além de ser a "única trilha concreta em direção à profissionalização para os escritores", a imprensa possibilitou ainda, através da publicidade, um incremento nos rendimentos dos escritores mais adaptados com a mercantilização das letras (SUSSEKIND, 2006: 74).
} 
esteve na delegacia para prestar o seu depoimento sobre o assassinato de Oscar Ferreira Mafra, vulgo Cambuca. O jornalista declarou que presenciou a confissão do acusado, Américo Vespúcio dos Santos, na noite do crime (dia 29 de março de 1900) ali mesmo na sede da $9^{\text {a }}$ circunscrição urbana (Arquivo do Museu da Justiça do Estado do Rio de Janeiro. Réu: Américo Vespúcio dos Santos; Ação: Homicídio; Ano: 1900, f.20-21). Com isso, podemos inferir que o jovem repórter foi designado para acompanhar a abertura da investigação policial. Possivelmente, ele ficou responsável pela coleta das informações que seriam utilizadas para a construção da notícia que seria estampada com destaque no dia seguinte.

De fato, diversos jornais deram publicidade para o assassinato ocorrido próximo ao botequim da Rua Visconde de Itaúna (O PAIZ, 30/03/1900: 1; A NOTÍCIA, 30/03/1900: 2; JORNAL DO BRASIL, 30/03/1900: 1; GAZETA DE NOTÍCIAS, 30/03/1900: 1). Inclusive, encontramos uma notícia que confirma que havia outros jornalistas presentes na delegacia na noite do assassinato. Segundo o relato da Cidade do Rio, O repórter d'A Notícia, Theophilo de Figueiredo, se ofereceu para defender o acusado. Em vista disso, Américo Vespúcio resolveu confessar o crime para o delegado. Nesta ocasião, estavam presentes os seguintes representantes da imprensa: o mencionado Theophilo de Figueiredo, "Henrique Autran, d'A Tribuna, e Osmundo Pimentel" (CIDADE DO RIO, 30/03/1900: 2, grifos nossos).

Neste caso em específico, podemos perceber que há uma coerência entre as informações presentes nos autos processuais com as notícias divulgadas pelos impressos cariocas. Nota-se que em algumas circunstâncias os jornalistas auxiliavam a polícia na revelação dos pormenores do crime. O acusado somente confessou o homicídio depois que um repórter se ofereceu para defendê-lo nas várias etapas do processo criminal. Isso nos indica que os repórteres tinham certa intimidade com a atividade forense, sobretudo por serem, em número considerável, bacharéis e/ou estudantes de Direito.

E quem era Henrique Autran, o nosso repórter que se transfigurou em testemunha num processo criminal? Vimos que no ano do crime, 1900, ele era repórter do jornal A Tribuna. No ano seguinte, Henrique tinha sido nomeado para o cargo de $2^{\circ}$ suplente da $10^{\text {a }}$ circunscrição (JORNAL DO BRASIL, 28/09/1901: 2). Cerca de três meses depois ele pediu dispensa do cargo acima referido (CORREIO DA MANHÃ, 27/06/1901: 2). O nosso repórter, mesmo sem ser advogado de formação, também trabalhou no foro atuando como solicitador e advogado provisionado (ALMANAQUE LAEMMERT, 1908: 848G). Já no ano de 1909, Henrique Autran era médico e havia se 
tornado membro da Academia Brasileira de Medicina (ALMANAQUE LAEMMERT, 1909: 2128). No início da década seguinte, em 1913, ele era um dos delegados de saúde da Capital Federal (ALMANAQUE LAEMMERT, 1913: 734).

Estas informações acerca desse indivíduo nos dão um interessante panorama da sua atuação profissional e dos caminhos percorridos por ele ao longo dos anos. Em pouco mais de uma década, Henrique Autran transitou por diversas áreas. Iniciou na imprensa como repórter policial, provavelmente quando ainda era estudante de medicina, passou rapidamente pelos quadros da polícia, mas, por fim, se notabilizou pelo trabalho desempenhado como médico.

Veremos alguns casos similares para acompanharmos a trajetória de outros funcionários da imprensa na primeira década do século XX. O repórter d'O Paiz, Jarbas do Aymorés de Carvalho, 24 anos, casado e morador da Rua Francisco Eugenio, 26A, também foi outro membro da imprensa que testemunhou em um auto processual. No dia 9 de março de 1900, na Rua do Mattoso, o alferes do Exército João Baptista Peres Almada assassinou sua esposa, Justina Cardoso Menezes de Souza e Almada. Este crime rapidamente ganhou grande repercussão no cotidiano da sociedade carioca. O excombatente de Canudos vitimou sua companheira com diversos golpes de faca na residência em que moravam.

Ali bem próximo, na mesma rua, estava situada a décima quarta delegacia policial. Em seu depoimento no sumário de culpa, o repórter Jarbas de Carvalho disse que tinha ido ao local "procurar o doutor delegado", mas não conseguiu encontrá-lo porque ele estava na "casa de um oficial que tinha acabado de assassinar a esposa" (Arquivo do Museu da Justiça do Estado do Rio de Janeiro. Réu: João Baptista Peres Almada; Ação: Homicídio; Ano: 1900, f.69-70). Em vista disso, o jornalista, "sem perda de tempo se dirigiu para a casa indicada" (idem). Na cena do crime, o repórter se deparou com o corpo da vítima "estendido sobre o assoalho da sala da frente" (idem).

Nesta ocasião, Jarbas de Carvalho perguntou para autoridade policial qual dos indivíduos presentes era o uxoricida. Em seguida, o repórter se dirigiu ao alferes e "este lhe confessou ter realmente assassinado sua esposa, que era adúltera" (idem). Novamente o jornalista retornou ao distrito policial acompanhado do delegado, dos seus auxiliares e do acusado. Ali, mais uma vez, o alferes admitiu, na presença do repórter/testemunha e de outras pessoas, ter sido o autor do homicídio.

Vemos que havia certa proximidade entre os funcionários da imprensa e a polícia. O depoimento de Jarbas de Carvalho corrobora esta assertiva. Segundo o repórter, 
sua presença na delegacia, a princípio, foi motivada por outros fatores. Como sugeriu Marialva Barbosa, muitas vezes era "necessária a presença física do jornalista para a apuração, quer pela importância do próprio acontecimento, quer pela recusa das autoridades em darem a informação pelo telefone, quer por outros motivos" (2010: 156). Logo, é possível supor que o repórter d'O Paiz foi para a delegacia em busca de informações privilegiadas sobre um crime sensacional ou sobre o rumo das investigações de outro caso misterioso.

No local, a testemunha tomou conhecimento do assassinato ocorrido nas imediações. Nesta ocasião, o jornalista "invadiu" a cena do crime, embora com a provável permissão da autoridade policial. Nota-se que o comportamento do jornalista se confunde muitas vezes com os dos funcionários policiais. Na casa do alferes, Jarbas de Carvalho inquiriu o acusado, trocou palavras com o delegado. Inclusive, o repórter acompanhou o depoimento do uxoricida na sede da delegacia. E qual foi à trajetória desse jornalista? Que caminhos ele percorreu nas páginas impressas? Em linhas gerais, no ano de 1922, Jarbas de Carvalho era diretor do jornal O Paiz (ALMANAQUE LAEMMERT, 1922: 526). Deste modo, após ter iniciado sua carreira como repórter policial, o jornalista alcançou um dos cargos mais altos na hierarquia dos jornais cariocas.

Nestes dois primeiros casos analisados, encontramos evidências que revelam que os jornalistas, em algumas situações, circulavam pelas repartições policiais e acompanhavam in loco os depoimentos dos acusados dos homicídios. Não obstante, encontramos um caso em que o repórter presenciou a prática do assassinato.

Na madrugada do dia 8 de outubro de 1901, no Largo da Carioca, às duas horas da madrugada, "um grupo de oito indivíduos discutia a princípio moderadamente, degenerando de repente a discussão em um conflito, havendo grossa pancadaria" (GAZETA DE NOTÍCIAS, 08/10/1901: 1). A "forte alteração" tomou maiores proporções quando o espanhol Francisco Peres Escudeiro, "no auge da cólera, vibrou uma punhalada no ventre de seu contendor" e patrício Antônio Marques (CORREIO DA MANHÃ, 09/10/1901: 2).

O jornalista Alfredo Seabra, 21 anos, solteiro, residente na rua Senador Furtado, 16, testemunhou nas distintas etapas do processo criminal. Esteve na sede da delegacia na madrugada do crime prestando o seu depoimento no auto de prisão em flagrante e também no sumário de culpa. Diante do magistrado, o jovem repórter disse que passava pelo Largo da Carioca quando avistou "um grupo composto de oito pessoas, homens e mulheres, estrangeiros todos e que alteravam sendo que mais tarde trocaram-se diversas 
cacetadas" (Arquivo do Museu da Justiça do Estado do Rio de Janeiro. Réu: Francisco Peres Escudeiro; Ação: Homicídio; Ano: 1901, f.28-29). Nesse instante, “prestando mais atenção", Alfredo Seabra declarou ter visto Francisco Peres, "armado de uma comprida faca de ponta", lutar com os demais participantes do conflito. No dia seguinte, segundo o jornalista, na "sua qualidade" de funcionário da imprensa, soube que a vítima falecera na Santa Casa de Misericórdia em consequência do ferimento recebido (idem).

Nota-se que o repórter se beneficiou do seu cargo para obter informações privilegiadas sobre o estado de saúde da vítima. As declarações do jornalista pouco esclareceram sobre os pormenores do conflito. De qualquer maneira, a trajetória de Alfredo Seabra nos dá uma perspectiva interessante sobre os caminhos trilhados pelos repórteres policiais do início do século XX.

No ano de 1902, ele era repórter d'A Notícia (ALMANAQUE LAEMMERT, 1902: 1567). No início do ano seguinte, Alfredo Seabra, como correspondente d'O Paiz, participou de uma inspeção na colônia correcional de Dois Rios. Segundo o relato do Jornal do Brasil, o jovem repórter sofreu muito durante a viagem de barco para Ilha Grande, e, "quanto mais ingeria remédios, mais enjoava" (JORNAL DO BRASIL, 10/01/1903: 1).

Em 1906, Alfredo Seabra era comandante da $9^{\text {a }}$ circunscrição urbana dos guardas noturnos (ALMANAQUE LAEMMERT, 1906: 291). Já em 1910, ele trabalhava no ministério da fazenda como terceiro escriturário da recebedoria do Rio de Janeiro. No início da década seguinte, Alfredo foi desligado do cargo no Tesouro Nacional "por ter sido designado pelo ministro da fazenda, para servir na Alfândega de Santos" (A NOTÍCIA, 16/01/1912: 2).

Vemos que este indivíduo exerceu diversas ocupações profissionais em um curto intervalo de tempo. Iniciou na imprensa como repórter policial, mas logo conseguiu "cavar" um cargo no funcionalismo público. Podemos conjecturar que a promoção foi facilitada devido a sua origem familiar, uma vez que seu pai, Gregório Garcia Seabra, era comendador (O PAIZ, 29/09/1908: 7). Afastado do labor diário da imprensa, Alfredo Seabra seguiu carreira no serviço de administração aduaneira. Em agosto de 1923, a revista $O$ Malho divulgou o "excelente" livro de sua autoria sobre A Tarifa Prática da Alfândega. Além dos pomposos elogios ao trabalho desempenhado por Alfredo Seabra, a notícia acompanha uma fotografia:

\section{Figura 1}


Alfredo Seabra

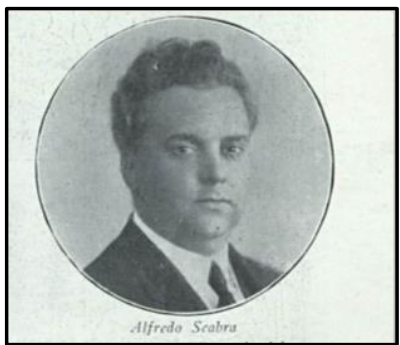

Fonte: O MALHO, 11/08/1923: 36.

Para encerramos a apreciação da trajetória dos funcionários da imprensa do início do século XX, resta apenas um último caso. No dia 25 de junho de 1902, o tesoureiro do Clube dos Democráticos, João Hipólito de Lima, vulgarmente conhecido como José da Costa, foi assassinado por Alfredo Pereira Paulo. Este crime ocorreu na Rua do Lavradio em frente ao Hotel Nacional. Segundo o noticiarista da Gazeta de Notícias, o homicídio "foi motivado por uma questão de somenos importância e praticado a falsa fé" pelo acusado que "vibrou nas costas da vítima uma facada" (GAZETA DE NOTÍCIAS, 26/06/1902: 2) .

Dois dias antes do crime, acompanhado por outros indivíduos, Alfredo Pereira Paulo teve a sua entrada vedada por Zé da Costa na portaria do Clube dos Democráticos. O tesoureiro alegou que estes indivíduos "se achavam atrasados em suas mensalidades, como também por não terem assinado o rateio para o (...) baile" (GAZETA DE NOTÍCIAS, 26/06/1902: 2). Em vista disso, o acusado ameaçou a vítima armado "com uma faca e jurou tirar desforra" (JORNAL DO BRASIL, 26/06/1902: 2). Nesta noite, diversas personalidades participavam do baile na casa de diversões carnavalescas. Entre elas, o segundo delegado auxiliar, Segadas Vianna Junior, o delegado da $3^{\text {a }}$ circunscrição urbana, Ayres da Rocha e o repórter policial, Henrique José Teixeira Guimarães.

Segundo o periodista do Correio da Manhã, "graças à intervenção" de uma autoridade policial, e de outros sócios do clube que ali se encontravam, o conflito não teve consequências mais desastrosas. A proibição feita por Zé da Costa causou "profundo sentimento a Alfredo que, mesmo à força, quis desobedecer" (CORREIO DA MANHÃ, 26/06/1902: 2). Por outro lado, segundo o relato do Jornal do Brasil, o "ligeiro conflito" foi apaziguado pelo repórter Guimarães que "conseguiu acalmar os ânimos, fazendo retirar” o grupo preterido (JORNAL DO BRASIL, 27/06/1902: 1). Na ânsia de acalmar "os desordeiros mais exaltados", este repórter "chegou a ser ferido em uma das mãos" (JORNAL DO BRASIL, 27/06/1902: 1). A Notícia também salientou “à intervenção 
enérgica de diversas pessoas presentes, entre as quais se achava um colega de imprensa, que foi ferido em um dos dedos da mão esquerda" (A NOTÍCIA, 26/06/1902: 2, grifo nosso).

Neste sentido, podemos observar que os referidos jornais deram versões diferentes para os desdobramentos do conflito que motivou o assassinato. Enquanto o Correio da Manhã deu ênfase na intervenção do delegado, o Jornal do Brasil e A Notícia sublinharam a valorosa mediação do repórter policial Henrique Guimarães. Inclusive, o periodista do Jornal do Brasil afirmou que "as autoridades presentes nenhuma providência tomaram, deixando por censurável proteção, que os desordeiros saíssem muito à vontade" (JORNAL DO BRASIL, 27/06/1902: 1). Em seguida, o jornalista conclui que se não fosse pela "inexplicável bondade das autoridades policiais em favor de desordeiros conhecidos, estariam presos e, de certo, não seria consumado o premeditado crime da Rua do Lavradio" (JORNAL DO BRASIL, 27/06/1902: 1).

Nota-se que tanto o Jornal do Brasil quanto A Notícia culparam a polícia pelo desfecho funesto. Segundo os impressos, a omissão dos delegados colaborou diretamente para a execução do intento criminoso. A ineficácia das autoridades, em contrapartida, foi compensada pelo poder de persuasão de um funcionário da imprensa. Assim sendo, veremos como os protagonistas e testemunhas depuseram no processo criminal.

Em seu depoimento no inquérito policial, no dia seguinte ao crime, o repórter da Gazeta de Notícias, Henrique José Teixeira Guimarães, 33 anos, casado e morador na Rua Visconde de Figueiredo, 1A, confirmou que esteve no Clube dos Democráticos assistindo um baile (Arquivo do Museu da Justiça do Estado do Rio de Janeiro. Réu: Alfredo Pereira Paulo; Ação: Homicídio; Ano: 1902, f.27-28). Inclusive, pelo depoimento de outra testemunha, percebemos que o jornalista realmente intercedeu no conflito. Arlindo Carneiro, 19 anos, solteiro, empregado na fábrica de toldos e morador no Beco dos Ferreiros, disse que o repórter "pediu a ele depoente e a Mario que se retirassem ao que acederam" (ibidem, f.21).

Por conseguinte, vemos que o repórter gozava de certa autoridade perante os populares. Arlindo e Mario acompanhavam o acusado quando na ocasião em que o tesoureiro do clube barrou a entrada deles. De acordo com Marialva Barbosa, havia o costume, durante o carnaval, "dos blocos e cordões saudarem os jornalistas" (BARBOSA, 2010: 176). Orestes Barbosa salientou esta proximidade em uma de suas crônicas. Após tecer diversos comentários elogiosos a imprensa em um baile na SDF Caprichosos da 
Estopa, um representante da casa oferece um brinde ao "seu Zizinho que sendo da imprensa é também pessoa diluída da nossa agremiação" (1993: 77).

Assim sendo, podemos conjecturar que os repórteres desfrutavam do prestígio que o seu cargo lhe conferia. Henrique Guimarães conseguiu apaziguar os ânimos dos indivíduos que ficaram de fora do baile. Seu procedimento preveniu o acirramento do conflito na portaria do Clube dos Democráticos. E quem era este jornalista? Que rumo ele trilhou nas páginas impressas? Em 1902, Henrique Guimarães trabalhava como repórter na Gazeta de Notícias. No dia 25 de março de 1908, este indivíduo, que também era tenente, "foi nomeado inspetor geral das guardas de vigilantes noturnos" (A IMPRENSA, 26/03/1908: 2). Dez anos mais tarde, Henrique Guimarães era intendente municipal da cidade do Rio de Janeiro (ALMANAQUE LAEMMERT, 1918: 976). Segundo Sidney Chalhoub, "os intendentes municipais são equivalentes aos atuais vereadores" (1996: 6).

Em síntese, vemos que a trajetória de Henrique Guimarães é muito parecida com os caminhos percorridos pelos demais repórteres que depuseram nos processos criminais consultados. Todos os jornalistas mencionados, à exceção do próprio Henrique Guimarães, tinham menos de 30 anos de idade. Eram, em sua grande maioria, jovens universitários que ingressavam nas redações ocupando, inicialmente, o cargo de repórteres policiais $^{6}$. Vale notar que todos os jornalistas rastreados residiam nas freguesias pericentrais da Capital Federal. Além disso, eles foram testemunhas dos crimes cometidos nas regiões pelas quais estes indivíduos circulavam no cotidiano. Ainda, podemos assegurar que Alfredo Seabra e Jarbas de Carvalho se conheciam, pois há registro fotográfico nas páginas impressas:

\section{Figura 2}

"Festas Joaninas à moda do Minho"

A contar da esquerda para a direita: Jarbas de Carvalho e Alfredo Seabra

\footnotetext{
${ }^{6}$ De acordo com Marialva Barbosa, repórter policial era o cargo pelo qual, "invariavelmente", começavam os que ingressavam nas redações. (BARBOSA, 2010, p.156).
} 


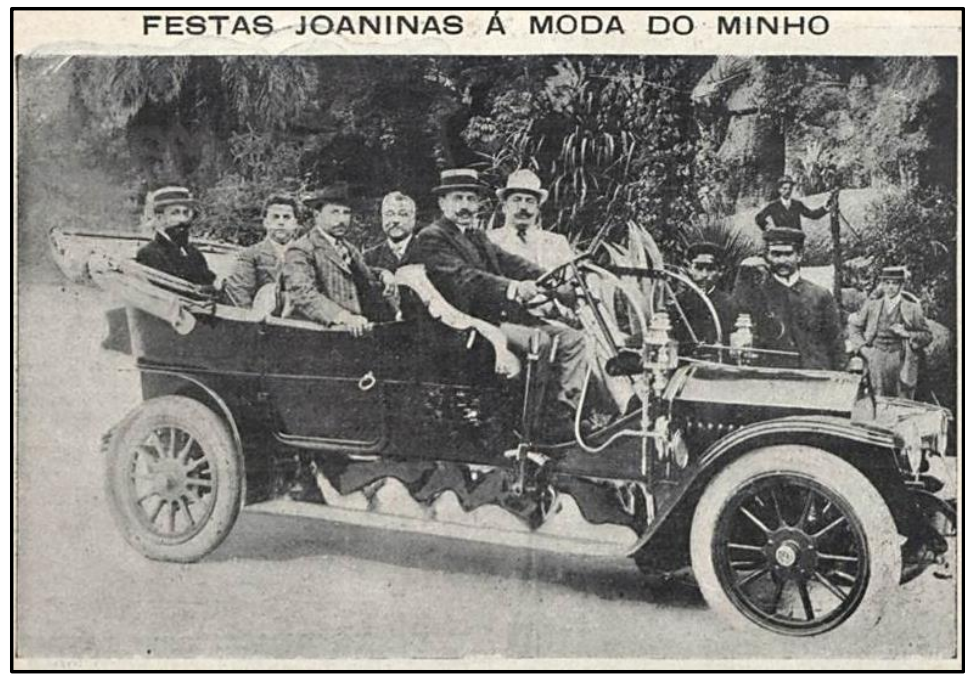

Fonte: O MALHO, Ano IX, N.401: 12.

Outra similaridade diz respeito às carreiras dos nossos repórteres. Todos os funcionários da imprensa conseguiram alguma situação de estabilidade financeira. A maior parte "cavou" um cargo na burocracia estatal. Alfredo Seabra no ministério da fazenda, Henrique Autran na repartição de higiene e Henrique Guimarães na intendência municipal. Jarbas de Carvalho foi o único que se manteve dedicado exclusivamente ao trabalho na imprensa. Iniciou como repórter policial e se transformou no diretor de um jornal tradicional da Capital Federal.

Por conseguinte, vemos que o Rio de Janeiro do início do século XX, como bem salientou Nicolau Sevcenko, oferecia "um campo ímpar de atuação para intelectuais em um país pobre a analfabeto" (1999: 94). Assim sendo, acreditamos que uma análise pormenorizada das trajetórias dos funcionários da imprensa nos permitiu visualizar a proximidade das empresas jornalísticas com o estado.

Como observamos na primeira secção do presente artigo, a demanda cultural do público foi fundamental para que houvesse uma diversificação no conteúdo dos jornais. Para aumentar o número de vendagens, os impressos passaram a divulgar as matérias sobre crimes cometidos no cotidiano da cidade, pois perceberam que essas notícias eram bem recebidas pelo público. Com isso, em certa medida, os populares tinham uma parcela dos seus interesses representados nas páginas dos impressos.

No entanto, os jornalistas construíam essas narrativas sempre procurando estigmatizar o ambiente em que viviam as camadas populares. Neste período os jornalistas tinham se tornado ditadores dos hábitos "civilizados". Para tanto, era necessário criticar o modo de vida daqueles que se negavam a adotar o novo estilo de vida 
desejado. Com o fito de se inserirem no centro do poder, os jornalistas ecoavam o discurso que condenava o comportamento dos segmentos populares.

Essa tendência se tornava mais nítida quando os crimes eram praticados nas regiões habitadas pelos mais necessitados, sobretudo quando eram cometidos nos morros cariocas. Em linhas gerais, nestas ocasiões os jornais não criticavam somente os homicidas pertencentes a estas comunidades, mas também os demais habitantes dessas localidades.

\section{Considerações finais}

Em conclusão, neste artigo procuramos analisar a trajetória de alguns repórteres que testemunharam nos processos criminais de assassinatos ocorridos na cidade do Rio de Janeiro na primeira década do século XX. Com este fito, seguimos os vestígios destes indivíduos nas páginas dos impressos cariocas. Por fim, observamos que os repórteres policiais rapidamente conseguiram cavar um cargo no serviço público. É possível supor que essas "promoções" foram oferecidas quando os repórteres ainda trabalhavam nas redações dos jornais cariocas.

Além disso, é interessante destacar a convergência das fontes analisadas. Os processos criminais e os jornais são complementares. O jornalista aparece como testemunha no processo criminal. Frequentemente, encontramos um recorte de jornal, a notícia do crime, anexado em um processo criminal. Em síntese, buscamos historicizar a relação íntima entre a imprensa, a justiça e a polícia. Vale ressaltar que esta estreita aproximação permanece em voga nos dias atuais.

\section{Fontes}

A IMPRENSA (1908)

ALMANAQUE LAEMMERT (1900-1922)

A NOTÍCIA (1900-1912)

BARBOSA, Orestes (1993 [1923]). Bambambã. Rio de Janeiro: Secretaria Municipal de Cultura, Turismo e Esportes.

CIDADE DO RIO (1900)

CORREIO DA MANHÃ (1901-1910)

EDMUNDO, Luís (2003 [1938]). O Rio de Janeiro do meu tempo. Edição do Senado Federal - Vol. 1.

GAZETA DE NOTÍCIAS (1900-1910)

JORNAL DO BRASIL (1900-1910) 
LOWENSTIMM, A (1905). Superstição e direito penal. Pecúlio para apreciação da influência dos preconceitos populares nas práticas de crime. Tradução: Alfredo Ansur. Porto: Livraria Chardron.

O MALHO (1910-1924)

O PAIZ (1900-1910)

RÉU: AMÉRICO VESPÚCIO DOS SANTOS, Ação: Homicídio; Ano: 1900. (Arquivo do Museu da Justiça do Estado do Rio de Janeiro).

RÉU: JOÃO BAPTISTA PERES ALMADA, Ação: Homicídio; Ano: 1900. (Arquivo do Museu da Justiça do Estado do Rio de Janeiro).

RÉU: FRANCISCO PERES ESCUDEIRO, Ação: Homicídio; Ano: 1901. (Arquivo do Museu da Justiça do Estado do Rio de Janeiro).

RÉU: ALFREDO PEREIRA PAULO, Ação: Homicídio; Ano: 1902. (Arquivo do Museu da Justiça do Estado do Rio de Janeiro).

\section{Referências Bibliográficas}

ALVARENGA NETO, Francisco de Paula (1933). Comédias e dramas judiciários. (Crônicas de processos célebres) 1912-1933. Rio de Janeiro: Ed. Marisa.

BARBOSA, Marialva (2010). História cultural da imprensa. Brasil (1800-1900). Rio de Janeiro: Mauad X. Imprensa, poder e público: os diários do Rio de Janeiro (1880-1920) INTERCOM

- Revista Brasileira de Comunicação. São Paulo, vol. XX, n. 2, pp.87-102, Jul./Dez. 1997. Disponível em: <http://www.epublicacoes.uerj.br/index.php/intellectus/about/submissions\#authorGuidelines $>$. Acesso em: 23 de fev. 2018.

BARRETO, Lima (1999 [1948]). Clara dos anjos. 2a Ed. São Paulo: Editora Escala. (s/d [1909]) Recordações do Escrivão Isaías Caminha. $2^{\mathrm{a}}$ Ed. São Paulo: Editora Escala. s/d.

CHALHOUB, Sidney (1996). Cidade febril. Cortiços e epidemias na corte imperial. São Paulo: Companhia das letras.

LUCA, Tania Regina de; MARTINS, Ana Luiza (Orgs.) (2011). História da Imprensa no Brasil. 2 ed. São Paulo: Contexto.

OTTONI, Ana Vasconcelos (2007). Flores do vício: imprensa e homicídios de meretrizes no Rio de Janeiro (1896-1925). Dissertação (Mestrado em História). Programa de Pós-Graduação em História Social, Universidade Federal do Rio de Janeiro, Rio de Janeiro.

(2012). "O paraíso dos ladrões": crime e criminosos nas reportagens policiais da imprensa (Rio de Janeiro, 1900-1920). Tese (Doutorado em História). Programa de Pós-Graduação em História, Universidade Federal Fluminense, Rio de Janeiro.

PORTO, Ana Gomes (2003). Crime em letra de forma: sangue, gatunagem e um misterioso esqueleto na imprensa do preludio republicano. Dissertação (Mestrado em História). Programa de Pós-Graduação em História, Universidade Estadual de Campinas, São Paulo.

(2009). Novelas sangrentas: literatura de crime no Brasil, (1870- 1920). Tese (Doutorado em História). Programa de Pós-Graduação em História, Universidade Estadual de Campinas, São Paulo.

SEVCENKO, Nicolau (1999). Literatura como missão. Tensões sociais e criação cultural na Primeira República. São Paulo: Editora Brasiliense. 
SODRÉ, Nelson Werneck (1999 [1966]). História da Imprensa no Brasil. $4^{\mathrm{a}}$ edição com capítulo inédito. Rio de Janeiro: Mauad.

SUSSEKIND, Flora (2006 [1987]). Cinematógrafo das letras. Literatura, técnica e modernização no Brasil. São Paulo: Companhia das letras.

SILVA, Eduardo (1988). As queixas do povo. Rio de Janeiro: Editora Paz e Terra.

Artigo recebido em 10 de fevereiro de 2018.

Aprovado em 22 de agosto de 2018.

DOI:10.12957/intellectus.2018.38976 